\title{
The antinociceptive effects of systemic administration of tramadol, gabapentin and their combination on mice model of acute pain
}

\author{
Farelerde akut ağrida sistemik uygulanan tramadol, gabapentin ve \\ kombinasyonlarmin antinosiseptifetkileri
}

Osman Nuri AYDIN,' Rauf Onur EK, ${ }^{2}$ Sadun TEMOÇiN, ${ }^{2}$ Bakiye UĞUR, ${ }^{3}$ Bilge ALAÇAM,,${ }^{3}$ Selda ŞEN ${ }^{3}$

\section{Summary}

Objectives: The aim of the present study was to investigate the possible antinociceptive effects of systemic administration of tramadol and gabapentin either alone or in combination on acute pain models in mice.

Methods: After obtaining the approval of Animal Ethics Committee; 96 BALB/c albino male mice were divided into 12 groups: (I) control without injection, (II) control treated with saline, (III)-(IV) mice treated with tramadol $10 \mathrm{mg} / \mathrm{kg}$ or 30 $\mathrm{mg} / \mathrm{kg}$, (V)-(VIII) mice treated with gabapentin; 30, 100, 200, $300 \mathrm{mg} / \mathrm{kg}$ respectively. In order to determine possible interactions between tramadol gabapentin and; mice received four different combinations of tramadol + gabapentin $(30+30,30+100$, $30+200$ and $30+300 \mathrm{mg} / \mathrm{kg}$ ) (Groups IX-XII respectively). Mice received $0.1 \mathrm{ml}$ solution for every $10 \mathrm{~g}$ of their weight. The drug was injected into peritonea. Thirty minutes after the drug injection, tail-flick and hot-plate tests were conducted.

Results: Ten and $30 \mathrm{mg} / \mathrm{kg}$ tramadol produced dose dependent antinociceptive effect in tail-flick and hot plate tests. Gabapentin had no antinociceptive effect in the tail flick test except $300 \mathrm{mg} / \mathrm{kg}$ dose, and had dose dependent antinociceptive effect in hot-plate test. In both tests, various combinations of tramadol and gabapentin produced an antinociceptive effect that is greater than that produced by tramadol and gabapentin alone. But, just $30 \mathrm{mg} / \mathrm{kg}$ tramadol $+300 \mathrm{mg} / \mathrm{kg}$ gabapentin combination caused statistically significant increase in both tests $(\mathrm{p}<0.05)$.

Conclusion: When gabapentin and tramadol were used in combination, gabapentin had no additive antinociceptive effect except for $300 \mathrm{mg} / \mathrm{kg}$ in tail-flick and hot-plate tests. Tail-flick test showed that tramadol produced better antinociceptive effect than gabapentin.

Key Words: Drug interaction; gabapentin; hot-plate; mice; nociception; tail-flic; tramadol.

Özet

Amaç: Tek başına veya birlikte sistemik olarak verilen tramadol ve gabapentinin farelerde akut ağrıda olası antinosiseptif etklerini araştırmaktır.

Gereç ve Yöntem: Hayvan etik komitesinin onayı sonrası; 96 BALB/c albino dişi fare 12 gruba ayrıldı: (I) Enjeksiyon yapılmaksizin kontrol grubu, (II) salin uygulanan kontrol grubu, (III)-(IV) tramadol $10 \mathrm{mg} / \mathrm{kg}$ veya $30 \mathrm{mg} / \mathrm{kg}$ uygulanan gruplar, (V)(VIII) gabapentinin strastyla 30, 100, 200, $300 \mathrm{mg} / \mathrm{kg}$ uygulandiğı gruplar idi. Tramadol ve gabapentinin olast etkileşimlerinin araşttrildığı gruplarda farelere tramadol+gabapentinin dört farklı dozları uygulandı; $(30+30,30+100,30+200 \mathrm{ve} 30+300 \mathrm{mg} /$ kg) (sırasıyla, Grup IX-XII). Farelerin her 10 gram ağırlı̆̆ için intraperitoneal olarak $0.1 \mathrm{~mL}$ ilaç uygulandı. Enjeksiyondan 30 dakika sonra tail-flick ve hot plate testleri gerçekleștirildi.

Bulgular: On ve $30 \mathrm{mg} / \mathrm{kg}$ tramadol tail-flick ve hot plate testlerinde doz bağımlı antinosiseptif etki oluşturdu. Gabapentin $300 \mathrm{mg} /$ $\mathrm{kg}$ dışındaki dozlarda tail-flick testinde antinosiseptif etki oluşturmazken, bot plate testinde doz bağımlı antinosiseptif etki oluşturdu. Her iki testte de tramadol ve gabapentin birlikte kullanıldiklarında, tek başlarına kullanılmalarına oranla daha fazla antinosiseptif etki oluşturdu, fakat sadece $30 \mathrm{mg} / \mathrm{kg}$ tramadol $+300 \mathrm{mg} / \mathrm{kg}$ gabapentin birlikte kullanildığtnda ber iki testte de anlamlt antinosiseptif etki saptand $(p<0.05)$.

Sonuç: Gabapentin ve tramadol birlikte kullanıldıklarında, tail-flick ve hot-plate testlerinde gabapentin $300 \mathrm{mg} / \mathrm{kg}$ dozu dişında additif antinosiseptif etki oluşturmad. Tail-flick testi sonuçlarına göre tramadol, gabapentinden daha iyi antinosiseptif etki oluşturdu.

Anahtar sözcükler: Illaç etkileşimi; gabapentin; hot-plate; fare; nosisepsiyon; tail-flick; tramadol.

Departments of ${ }^{1}$ Anesthesiology and Reanimation/Algology, ${ }^{2}$ Physiology, ${ }^{3}$ Anesthesiology and Reanimation,

Adnan Menderes University Faculty of Medicine, Aydın, Turkey

Adnan Menderes Universitesi Tıp Fakütesi, 'Anesteziyoloji/Algoloji Bölümü, ${ }^{2}$ Fizyoloji Anabilim Dalı, ${ }^{3}$ Anesteziyoloji ve Reanimasyon Anabilim Dalı, Aydın

Submitted (Başvuru tarihi) 08.10.2010 Accepted after revision (Düzeltme sonrası kabul tarihi) 04.11.2011

Correspondence (IIletişim): Osman Nuri Aydın M.D. Adnan Menderes Üniversitesi Tıp Fakültesi, Algoloji Bilim Dalı, 09100 Aydın, Turkey

Tel: +90 - 256 - 444 1256/ 2103 e-mail (e-posta): onaydin@superonline.com 


\section{Introduction}

Gabapentin (GBP) is an anticonvulsive drug and clinical studies have shown that GBP is effective on diabetical neuropathy, postherpetical neuralgia and reflex sympathetic dystrophy pains. ${ }^{[1-3]}$

In animal models, it was observed that GBP reduced nociception in mechanical or thermal hyperalgesia, peripheral nerve injury, incisional injury, inflammation injury, and injury related to formalin ${ }^{[4-6]}$ While GBP that is applied systematically or intrathecally is not effective on acute thermal nociception, it is effective on the nociception related to substance $\mathrm{P}$ injection, pressure and formalin injection. ${ }^{[4,7]}$

GBP is a drug that shares a similar structure to that of GABA, although its mechanism of action cannot be explained solely by a direct gaba mimetic effect. [8-10]

It is believed that GBP shows its effect with selective inhibitory effect on voltage-gated calcium channels containing the alpha 2 delta- 1 subunit. ${ }^{[1]}$ This effect is derived from the up-regulation of spinal cord and dorsal root ganglion resulting from peripheral injury. ${ }^{[12]}$ GBP generates antihyperalgesia by reducing the glutaminergical transmission to the spinal cord. In addition, GBP can inhibit central sensitization and thermal hyperalgesia that correlates with central sensitization. This effect stems from the direct postsynaptical $\mathrm{Ca}^{+2}$ influx of voltage dependent $\mathrm{Ca}^{+2}$ channels or the reduction of excitatory aminoacide which results from presynaptical $\mathrm{Ca}^{+2}$ influx. ${ }^{[13]}$

Tramadol is a centrally acting weak opioid analgesic drug that is used in the management of pain. ${ }^{[14]}$ Experimental data suggest that tramadol exerts its analgesic effect through the activation of the central inhibitory monoaminergic pathway because its effect has been partially blocked by alpha-adrenoreceptor antagonists ${ }^{[15]}$ as well as it works as an opioid.

The various interactions might be considered, additive, synergistic, or antagonistic. When two or more drugs are combined, these may produce independent effects (no relation) or effects may be equal to the sum of the effects of each (additive effect). Some pharmacologic agents may inhibit or reduce each other's effects (antagonism), or the effect observed may be more than the one excepted (synergy). ${ }^{[15]}$

The purpose of this study was to determine the antinociceptive effects of systemic administration of systemic tramadol, gabapentin and their combination on mice model of acute pain.

\section{Material and Methods}

\section{Animals}

Male Balb/c albino mice weighing 26-38 g were used. The animals were maintained in a temperature controlled $\left(23 \pm 1^{\circ} \mathrm{C}\right)$ colony room under a $12 \mathrm{~h}$ daynight cycle, they were housed 12 per cage in plastic cages, and were given access to food and water ad libitum. The animals received a 1 week habituation period before the experimental procedures were initiated, during which time theywere handled daily. All experiments were performed in accordance with the guidelines for animal research from the National Institutes of Health (NIH publication No. 86-23, revised 1985). All experimental protocols were approved by the Animal Care and Use Committee of the Adnan Menderes University, and were carried according to Helsinki Declaration.

\section{Experimental groups}

The animals divided randomly into 12 groups.

Control g.: Mice were injected no drug and served as control group.

Group II: Mice were injected saline intraperitoneally (i.p.) and served as saline group.

Group III: Mice were injected $10 \mathrm{mg} / \mathrm{kg}$ tramadol (i.p.)

Group IV: Mice were injected $30 \mathrm{mg} / \mathrm{kg}$ tramadol (i.p.)

Group V: Mice were injected $30 \mathrm{mg} / \mathrm{kg}$ gabapentin (i.p.)

Group VI: Mice were injected $100 \mathrm{mg} / \mathrm{kg}$ gabapentin (i.p.)

Group VII: Mice were injected $200 \mathrm{mg} / \mathrm{kg}$ gabapentin (i.p.)

Group VIII: Mice were injected $300 \mathrm{mg} / \mathrm{kg}$ gabapentin (i.p.)

Group IX: Mice were injected $30 \mathrm{mg} / \mathrm{kg}$ tramadol 
$+30 \mathrm{mg} / \mathrm{kg}$ gabapentin (i.p.)

Group IX: Mice were injected $30 \mathrm{mg} / \mathrm{kg}$ tramadol $+100 \mathrm{mg} / \mathrm{kg}$ gabapentin (i.p.)

Group XI: Mice were injected $30 \mathrm{mg} / \mathrm{kg}$ tramadol $+200 \mathrm{mg} / \mathrm{kg}$ gabapentin (i.p.)

Group XII: Mice were injected $30 \mathrm{mg} / \mathrm{kg}$ tramadol $+300 \mathrm{mg} / \mathrm{kg}$ gabapentin (i.p.)

Equipotent dose for mice is 12 times of human dose. ${ }^{[16,17]}$ Tramadol dose is $1-2 \mathrm{mg} / \mathrm{kg}$ for human, so we used 10 and $30 \mathrm{mg} / \mathrm{kg}$ tramadol in mice treatments. Gabapentin was given maximally $3600 \mathrm{mg} /$ day for human. ${ }^{[2,8]}$ In spite of equipotent dose for mice is approximately $100 \mathrm{mg} / \mathrm{kg}$. Because of antinociceptive effect of gabapentin on acute pain and interaction was investigated between tramadol and gabapentin, we tested $30,100,200$, and $300 \mathrm{mg} / \mathrm{kg}$ doses of gabapentin.

\section{Preparation of drugs and injection}

Gabapentin (Neurontin $300 \mathrm{mg}$ caps, Pfizer) and tramadol (Contramal amp, $100 \mathrm{mg} / \mathrm{amp}$, Abdi Ibrahim) were diluted with saline (S). $300 \mathrm{mg}$ Neurontin caps was diluted with saline, and mice received intraperitoneally $0.1 \mathrm{~mL}$ solution for every $10 \mathrm{~g}$ of their weight. For example Neurontin $300 \mathrm{mg}$ cap was diluted with $30 \mathrm{ml}$ saline and $0.3 \mathrm{ml}$ solution was given intraperitoneally for $30 \mathrm{~g}$ of $100 \mathrm{mg} / \mathrm{kg}$ gabapentin treated mouse.

\section{Tests}

Tail-flick test was preferred as a measure of the response to thermal nociceptive up-regulations, and it is used in the determination of spinal reflex. ${ }^{[1]}$ The hot-plate test was preferred in the determination of the effects of the central affectivity.

\section{Tail-flick test (TFT)}

The tail flick latency, defined by the time (in seconds) of withdrawal of the tail from a radiant heat source (bulb, $8 \mathrm{~V} / 50 \mathrm{~W}$ ), was measured via the usage of a semiautomated device (tail flick analgesiemeter; May Tic., Ankara). After the placement of the tails of the mice into the apparatus in accordance with the procedure, and activation of the apparatus at $55 \%$ power, the period required flicking of the tails of the mice was calculated as tail-flick period. Constant heat intensity was applied to the dorsum of the upper third of tails of the mice and when the mouse flicked its tail in response to the noxious thermal stimulus, both the heat source and the timer stopped automatically. A cut off time of 20 seconds (3-4 times more than the basal tail-flick period) was imposed to prevent any injury to the tail. The nociceptive threshold was observed before the study, and 30 minutes after the drug administration.

\section{Hot-plate test (HPT)}

The apparatus (May Tr., Ankara), was heated up to $\left(56 \pm 0.3^{\circ} \mathrm{C}\right)$ and prepared for the test. The researchers did not know to which group the mice belonged (O.E). When shoe-flick behavior (flicking and raising up foot, shaking- waving, licking foot) was observed, the chronometer of the apparatus was stopped. The latency to the first sign of hind paw licking, or the jump response to avoid heat nociception was taken as an index of nociceptive threshold. The nociceptive threshold was investigated at the beginning of study, and 30 minutes after the drug administration. A cut off time of 20 seconds was imposed to prevent any injury to the foot.

\section{Statistical analysis}

All results are expressed as mean (SEM). The tailflick and hot-plate latencies, before and after the application of drugs, were determined by using the nonparametric Kruskal Wallis test for multiple samples. Kruskal Wallis post hoc test was used to determine statistical significance between the groups. $\mathrm{p}<0.05$ was set as the level of statistical significance.

\section{Results}

\section{Effects of i.p administered tramadol and gabap- entin alone in tail-flick test}

To test for possible analgesic action on acute nociceptive processing, drugs were administered to mice in the tail-flick test. In the tail-flick test there was no statistical difference between the control group and the saline treated group $(4.37 \pm 0.70$ and $5.78 \pm 2.01$ $s$ respectively). On the other hand $10 \mathrm{mg} / \mathrm{kg}$ and $30 \mathrm{mg} / \mathrm{kg}$ TRM treatment statistically increased 
tail-flick latencies with dose-dependent fashion $(9.16 \pm 2.71$ and $13.03 \pm 4.12 \mathrm{~s})(\mathrm{p}<0.05)$. There were no significant changes observed in tail-flick test when mice treated with 30,100 and $200 \mathrm{mg} / \mathrm{kg}$ doses of GBP $(6.27 \pm 0.70,6.50 \pm 0.91$ and $6.81 \pm 1.12$ $s$ respectively). However, $300 \mathrm{mg} / \mathrm{kg}$ GBP treatment statistically increased tail-flick latency $(11.48 \pm 4.30$ s) $(\mathrm{p}<0.05)$.

\section{Effects of i.p administered tramadol and gabap- entin alone in hot-plate test}

In the hot-plate test there was no statistical difference between the control group and the saline treated group $(4.13 \pm 1.53$ and $4.23 \pm 0.70 \mathrm{~s}$ respectively). However, 10 and $30 \mathrm{mg} / \mathrm{kg}$ TRM treatment statistically increased hot-plate latencies $(9.91 \pm 2.31$ and $11.41 \pm 1.54 \mathrm{~s})(\mathrm{p}<0.05)$. GBP treatment with $30,100,200$ and $300 \mathrm{mg} / \mathrm{kg}$ doses caused statistically significant increase in hot-plate latencies $(7.75 \pm 1.52,7.87 \pm 2.20,8.10 \pm 1.67$ and $9.37 \pm 2.62$ $\mathrm{s}$ respectively) $(\mathrm{p}<0.05)$. There were no significant changes observed between GBP groups.

\section{Effects of combined of tramadol and gabapentin tail-fick and hot-plate test}

Dose-dependent antinociceptive effects of the drug combinations a tail-flick and hot-plate tests were shown in Fig.1 and Fig. 2. In both tail-flick and hotplate tests, various combinations of TRM and GBP produced an antinociceptive effect that is greater than that produced by TRM and GBP alone. On

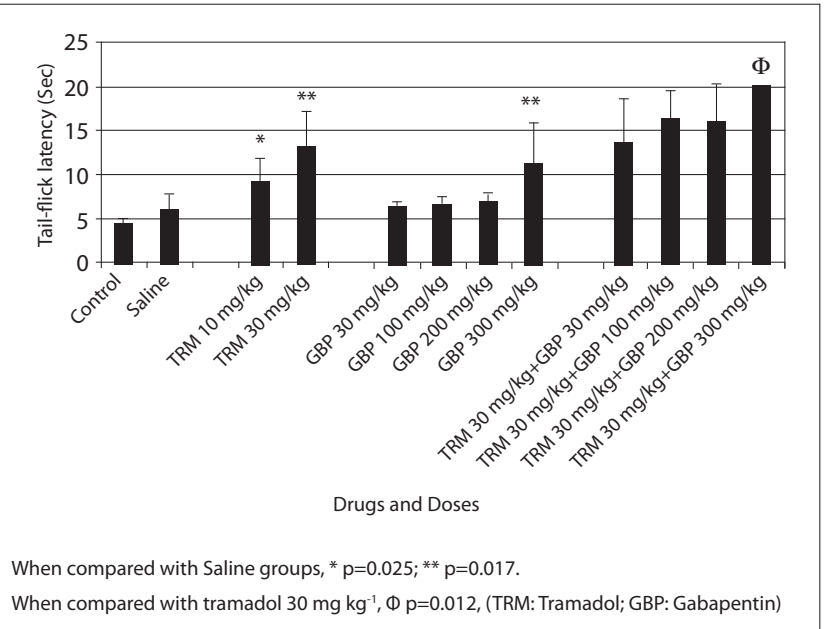

Fig 1. Effect of tramadol, gabapentin, and tramadol + gabapentin on tail-flick test. the other hand, only $30 \mathrm{mg} / \mathrm{kg}$ TRM $+300 \mathrm{mg} /$ $\mathrm{kg}$ GBP combination caused statistically significant increase in both tests $(\mathrm{p}<0.05)$. Other combinations of TRM+GBP were not significant for alone doses of TRM or GBP.

\section{Discussion}

It was concluded that TRM is more effective than gabapentin on acute thermal pain in tail-flick test. GBP was not effective on nociception in acute thermal pain, and combination of gabapentin with tramadol has no positive contribution to the antinociception.

The antinociceptive effect mechanism of GBP is believed that GBP shows its effect by means of GABA, NMDA, adenosine receiver and $\mathrm{L}$-arginine nitric oxide or $\mathrm{Ca}^{+2}$ channels. Despite the fact that gabapentine increases the synthesis and oscillation of $\mathrm{GABA}^{[18]}$ intrathecal (i.t.) application of the receptor antagonists of GABAA and GABAB cannot turn back the effect of GBP. ${ }^{[18,19]}$ While there is no proof that GBP is directly linked to the spinal NMDA receptor; D-serine, a NMDA receptor agonist, can turn back the antinoniceptive effect of GBP. ${ }^{[20]}$ All these findings make one think that GBP generates its effect through NMDA receptors. ${ }^{[21]}$ Bryans et al. ${ }^{[18]}$ speculated that GBP shows its effect with the $\mathrm{Ca}^{+2}$ channels in consequence of the connection of voltage sensitive $\mathrm{Ca}^{+2}$ channels to the $\alpha_{2} \delta_{1}$ subunit. The calcium re-uptake inhibitor is minimally effective on the effect of GBP. ${ }^{[19]}$ Furthermore, the

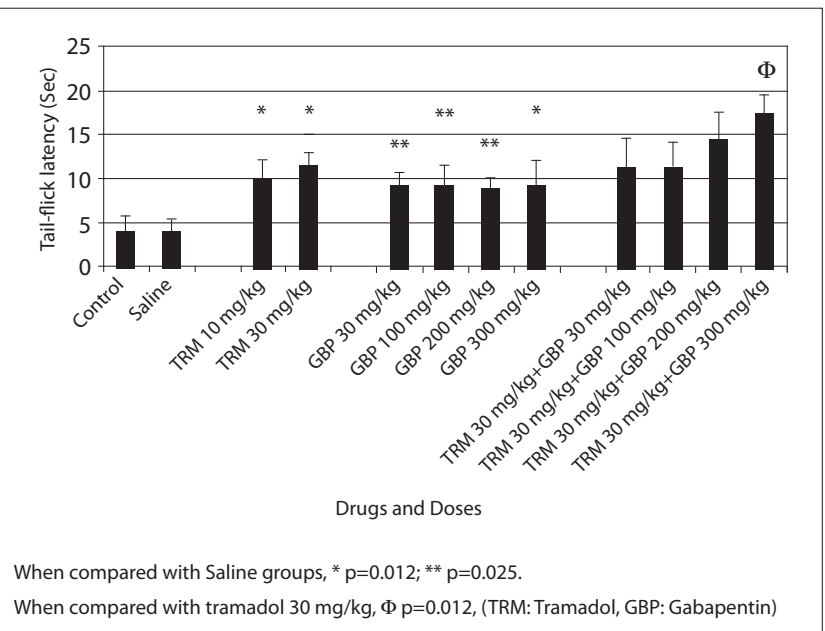

Fig 2. Effect of tramadol, gabapentin, and tramadol + gabapentin on hot-plate test. 
antinociceptive effect of GBP is more powerful in i.t. application than it is in its systematical application $^{[6]}$; therefore, it is thought that the area on which GBP has major effect is the spinal cord. ${ }^{[5,19]}$ While GBP is given systematically and intrathecally reduces the hyperalgesia in the animals with pain related to tissue trauma, ${ }^{[6,7,20]}$ it is not definitely effective on acute pain. ${ }^{[7,20,22]}$

Field and colleagues ${ }^{[6]}$ emphasized that in the animal models upon which postoperative pain is studied, GBP prevented allodinia and hyperalgesia development, and in rats with acute herpetical pain, systematic or intrathechal GBP reduced both allodinia and hyperalgesia depending on the dosage. It was stressed that in animal models GBP reduced nerve injury, inflammation and hypersensitivity that stems from postoperative pain. ${ }^{[6,20,22]}$

After the i.t. usage of GBP or following its pre-emptive disposition postoperative pain reduces and the requirement of postoperative opioid decreases. ${ }^{[23,24]}$ When GBP is applied systematically, foot-flick and foot-lick are prevented after $2.5 \%$ of formalin hence it is believed that GBP shows its effect systematically and it is effective on allodinia and hyperalgesia rather than nociception. ${ }^{[25]}$ It is demonstrated that GBP is not effective on transient pain models (tailflick), but only on the models with peripheral tissue injury or nerve legions that result in hyperalgesia or allodinia. ${ }^{[5,6]}$

Shimoyama et al. ${ }^{[7]}$ when applying i.p. GBP to rats observed meaningful pressurizing in foot-flick after 10 minutes (phase 2) in formalin test and emphasized that this effect takes place with the central sensitization. They mentioned that GBP is not effective on the acute pain depending on surgical injury. As we demonstrated in our study, GBP not having any effects on $\mu$ receptor, and not being effective on the tail-flick test explains nociception. GBP is effective on the hot-plate test due to its central effect.

GBP and morphine combination with subanesthesic dose increases the antinoniceptive effect in tail-flick test. This test is an opioid sensitive test by which the analgesic effects of opioids are researched. Since the antinoniceptive effect decreases or increases depending on the spinal morphine dosage, and since opioid antagonists (nalokson) reduce with the effect, it is thought that antinoniception is formed with $\mu$ receptor. ${ }^{[26]}$

It is known that TRM is an opioid analogue affects through $\mu$ receptors on acute pain. ${ }^{[27]}$ We concluded that TRM has an antinoniceptive effect on acute thermal pain in the tail-fick test.

Antihyperalgesic drugs like GBP can assume roles in postoperative pain, and their combination with other antinoniceptive medicine can generate synergistic effect. ${ }^{[28]}$ The essential purpose of combining different analgesics is to provide synergistic and additive analgesia by using low and secure dosages of each drug. ${ }^{[22]}$ Due to the variety of the mechanisms that generate pain, usage of opioid and nonopioid analgesic in addition to centrally or peripherally effective drugs, decreases the side effect and the opioid requirement. ${ }^{[29]}$

We planned our study, in addition to studying the additive/synergistic effect of using the TRM effective on both the central and $\mu$ receptors together with GBP, perceiving the lack of studies in which these are used together, based on our literature review.

It was shown that GBP increases the analgesic effect of morphine in volunteers, ${ }^{[23,28]}$ and in the patients with neuropathic cancer pain. When added into the morphine it provided longer analgesia than morphine received alone. ${ }^{[29]}$ Turan et al. ${ }^{[28]}$ mentioned that GBP that is used preoperatively reduces pain scores in the early postoperative period and the postoperative morpine consumption diminishes.

The tonic phase of formalin shows central sensitivity. GBP, by affecting the dorsal horn directly and indirectly, blockades the activation and pressurizes central sensitivity. Spinal GBP and morphine combination, effective on dorsal horn, pressurizes the presynaptical $\mu$ receptors. ${ }^{[30]}$ The i.t. usage of GBP in clinic has not been possible in recent times. We can think that i.t. usage of GBP in combination with TRM and other analgesics can be more effective on thermal and acute pain treatment in the future.

In our study we did not observe the additive/synergistical effect of TRM supplied with GBP. We think 
that our usage of both drugs in a systematic way (i.p.) instead of i.t., $\mu$ receptors less than morphine, and also usage of the acute thermal pain model, resulted in the inability to determine the additive effect formation.

Hurley et al. ${ }^{[31]}$ on a systematic review showed that perioperative oral GBP is a useful adjunct for the management of postoperative pain that provides analgesia through a different mechanism than opioids and other analgesic agents and would make a reasonable addition to a multimodal analgesic treatment plan.

In summary, it was observed that TRM is antinociceptively effective on the acute thermal pain; GBP is not effective on the acute pain, although it generates antihyperalgesia with the central effect. When GBP and TRM are used together in the acute attacks of neuropathic pain will not generate additive and synergistic effect in regular doses.

\section{Acknowledgement}

This study was supported by Research Fund Center of Adnan Menderes University.

\section{References}

1. Rosner H, Rubin L, Kestenbaum A. Gabapentin adjunctive therapy in neuropathic pain states. Clin J Pain 1996;12(1):568.

2. Rowbotham M, Harden N, Stacey B, Bernstein P, Magnus-Miller L. Gabapentin for the treatment of postherpetic neuralgia: a randomized controlled trial. JAMA 1998;280(21):1837-42.

3. van de Vusse AC, Stomp-van den Berg SG, Kessels AH, Weber WE. Randomised controlled trial of gabapentin in Complex Regional Pain Syndrome type 1 [ISRCTN84121379]. BMC Neurol 2004;4:13.

4. Jun JH, Yaksh TL. The effect of intrathecal gabapentin and 3-isobutyl gamma-aminobutyric acid on the hyperalgesia observed after thermal injury in the rat. Anesth Analg 1998;86(2):348-54.

5. Chapman V, Suzuki R, Chamarette HL, Rygh LJ, Dickenson $\mathrm{AH}$. Effects of systemic carbamazepine and gabapentin on spinal neuronal responses in spinal nerve ligated rats. Pain 1998;75(2-3):261-72.

6. Field MJ, Holloman EF, McCleary S, Hughes J, Singh L. Evaluation of gabapentin and S-(+)-3-isobutylgaba in a rat model of postoperative pain. J Pharmacol Exp Ther 1997;282(3):12426.

7. Shimoyama N, Shimoyama M, Davis AM, Inturrisi CE, Elliott $\mathrm{KJ}$. Spinal gabapentin is antinociceptive in the rat formalin test. Neurosci Lett 1997;222(1):65-7.

8. Sancho-Rieger J. Characteristics and indications of gabapentin. Rev Neurol 2002;35 Suppl 1:S85-7. [Abstract]
9. Bee LA, Dickenson AH. Descending facilitation from the brainstem determines behavioural and neuronal hypersensitivity following nerve injury and efficacy of pregabalin. Pain 2008;140(1):209-23.

10. Takeuchi Y, Takasu K, Ono H, Tanabe M. Pregabalin, S-(+)-3isobutylgaba, activates the descending noradrenergic system to alleviate neuropathic pain in the mouse partial sciatic nerve ligation model. Neuropharmacology 2007;53(7):84253.

11. Sills GJ. The mechanisms of action of gabapentin and pregabalin. Curr Opin Pharmacol 2006;6(1):108-13.

12. Luo ZD, Chaplan SR, Higuera ES, Sorkin LS, Stauderman KA, Williams $M E$, et al. Upregulation of dorsal root ganglion (alpha)2(delta) calcium channel subunit and its correlation with allodynia in spinal nerve-injured rats. J Neurosci 2001;21(6):1868-75.

13. Hurley RW, Chatterjea D, Rose Feng M, Taylor CP, Hammond DL. Gabapentin and pregabalin can interact synergistically with naproxen to produce antihyperalgesia. Anesthesiology 2002;97(5):1263-73.

14. Raffa RB, Friderichs E. The basic science aspect of tramadol hydrochloride. Pain Rev 1996;3:249-71.

15. Raffa RB, Friderichs E, Reimann W, Shank RP, Codd EE, Vaught JL. Opioid and nonopioid components independently contribute to the mechanism of action of tramadol, an 'atypical' opioid analgesic. J Pharmacol Exp Ther 1992;260(1):275-85.

16. Freireich EJ, Gehan EA, Rall DP, Schmidt LH, Skipper HE. Quantitative comparison of toxicity of anticancer agents in mouse, rat, hamster, dog, monkey, and man. Cancer Chemother Rep 1966;50(4):219-44.

17. FDA Guidance for Industry. Estimating the Maximum Safe Starting Dose in Initial Clinical Trials for Therapeutics in Adult Healthy Volunteers. Food and Drug Administration Center for Drug Evaluation and Research (CDER) July 2005 Pharmacology and Toxicology. Available from: http://www.fda.gov/ downloads/Drugs/GuidanceComplianceRegulatorylnformation/Guidances/ucm078932.pdf.

18. Bryans JS, Davies N, Gee NS, Dissanayake VU, Ratcliffe GS, Horwell DC, et al. Identification of novel ligands for the gabapentin binding site on the alpha2delta subunit of a calcium channel and their evaluation as anticonvulsant agents. J Med Chem 1998;41(11):1838-45.

19. Yoon MH, Choi Jl, Jeong SW. Spinal gabapentin and antinociception: mechanisms of action. J Korean Med Sci 2003;18(2):255-61.

20. Singh L, Field MJ, Ferris P, Hunter JC, Oles RJ, Williams RG, et al. The antiepileptic agent gabapentin (Neurontin) possesses anxiolytic-like and antinociceptive actions that are reversed by D-serine. Psychopharmacology (Berl) 1996;127(1):1-9.

21. Yoon MH, Choi Jl, Kwak SH. Characteristic of interactions between intrathecal gabapentin and either clonidine or neostigmine in the formalin test. Anesth Analg 2004;98(5):13749.

22. Hunter JC, Gogas KR, Hedley LR, Jacobson LO, Kassotakis L, Thompson J, et al. The effect of novel anti-epileptic drugs in rat experimental models of acute and chronic pain. Eur J Pharmacol 1997;324(2-3):153-60.

23. Eckhardt K, Ammon S, Hofmann U, Riebe A, Gugeler N, Mikus G. Gabapentin enhances the analgesic effect of morphine in healthy volunteers. Anesth Analg 2000;91(1):185-91.

24. Turan A, Karamanlioğlu B, Memiş D, Usar P, Pamukçu Z, Türe $M$. The analgesic effects of gabapentin after total abdominal 
hysterectomy. Anesth Analg 2004;98(5):1370-3.

25. Heughan CE, Sawynok J. The interaction between gabapentin and amitriptyline in the rat formalin test after systemic administration. Anesth Analg 2002;94(4):975-80.

26. Shimoyama M, Shimoyama N, Inturrisi CE, Elliott KJ. Gabapentin enhances the antinociceptive effects of spinal morphine in the rat tail-flick test. Pain 1997;72(3):375-82.

27. Edwards JE, McQuay HJ, Moore RA. Combination analgesic efficacy: individual patient data meta-analysis of single-dose oral tramadol plus acetaminophen in acute postoperative pain. J Pain Symptom Manage 2002;23(2):121-30.

28. Turan A, Karamanlioğlu B, Memiş D, Hamamcioglu MK, Tükenmez B, Pamukçu Z, et al. Analgesic effects of gabapentin after spinal surgery. Anesthesiology 2004;100(4):935-8.

29. Gilron I, Biederman J, Jhamandas K, Hong M. Gabapentin blocks and reverses antinociceptive morphine tolerance in the rat paw-pressure and tail-flick tests. Anesthesiology 2003;98(5):1288-92.

30. Coderre TJ, Vaccarino AL, Melzack R. Central nervous system plasticity in the tonic pain response to subcutaneous formalin injection. Brain Res 1990;535(1):155-8.

31. Hurley RW, Cohen SP, Williams KA, Rowlingson AJ, Wu CL. The analgesic effects of perioperative gabapentin on postoperative pain: a meta-analysis. Reg Anesth Pain Med 2006;31(3):237-47. 